\title{
BUB1B wt Allele
}

National Cancer Institute

\section{Source}

National Cancer Institute. BUB1B wt Allele. NCI Thesaurus. Code C95593.

Human BUB1B wild-type allele is located in the vicinity of $15 q 15$ and is approximately 60 $\mathrm{kb}$ in length. This allele, which encodes mitotic checkpoint serine/threonine-protein kinase BUB1 beta protein, plays a role in the modulation of protein phosphorylation and mitotic spindle checkpoint control. Mutation of the gene is associated with colorectal cancer, mosaic variegated aneuploidy syndrome and premature chromatid separation trait and may be involved in other carcinomas. 